\title{
Swollen right leg: Is it deep vein thrombosis?
}

\author{
William Lee, Keith Siau
}

Bassetlaw Hospital, Worksop, UK

\section{Correspondence to} Dr William Lee,

william_22_lee@hotmail.co.uk
CrossMark

To cite: Lee W, Siau K. BMJ Case Rep Published online: [please include Day Month Year] doi:10.1136/bcr-2013202066

\section{DESCRIPTION}

A 72-year-old man, with known atrial fibrillation on anticoagulation, presents to the general practitioner with a 1-week history of a new tender, right swollen leg. The popliteal pulse was not palpable due to oedema. Distal pulses were present with no neurological deficit. The patient was referred to the accident and emergency department for deep vein thrombosis exclusion.

Other more common differentials to consider were: ruptured Baker's cyst, chronic venous leg insufficiency, infection, trauma, lymphoedema and malignancy. ${ }^{1}$

The ultrasound Doppler did not identify a deep vein thrombosis and the patient was discharged. A fortnight later, the patient was re-admitted with hypotension and a palpable pulsatile, fluid mass at the right popliteal fossa. Distal foot pulses were diminished and there was no neurological deficit. Repeat ultrasound Doppler revealed a large right popliteal artery aneurysm (figure 1). Urgent CT angiogram of the legs showed that this aneurysm had ruptured (figure 2). The patient did not survive this admission.

Popliteal artery aneurysms are defined as having a diameter $>0.7 \mathrm{~cm}$. Prevalence is $1 \%$ in males, aged $65-80$ years. It is caused by arteriosclerosis and is often associated with additional aneurysms elsewhere. Indications for surgical intervention include leg swelling, pain, aneurysm rupture and/or if the popliteal artery aneurysm is $>2 \mathrm{~cm}$. Complications include acute ischaemia secondary to thrombosis. ${ }^{2}$ This is an unusual

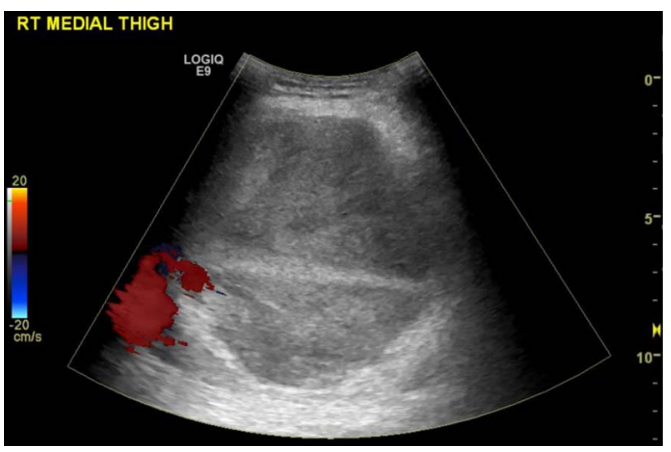

Figure 1 Ultrasound Doppler scan of the right popliteal artery aneurysm measuring $\sim 11 \times 10 \mathrm{~cm}$.

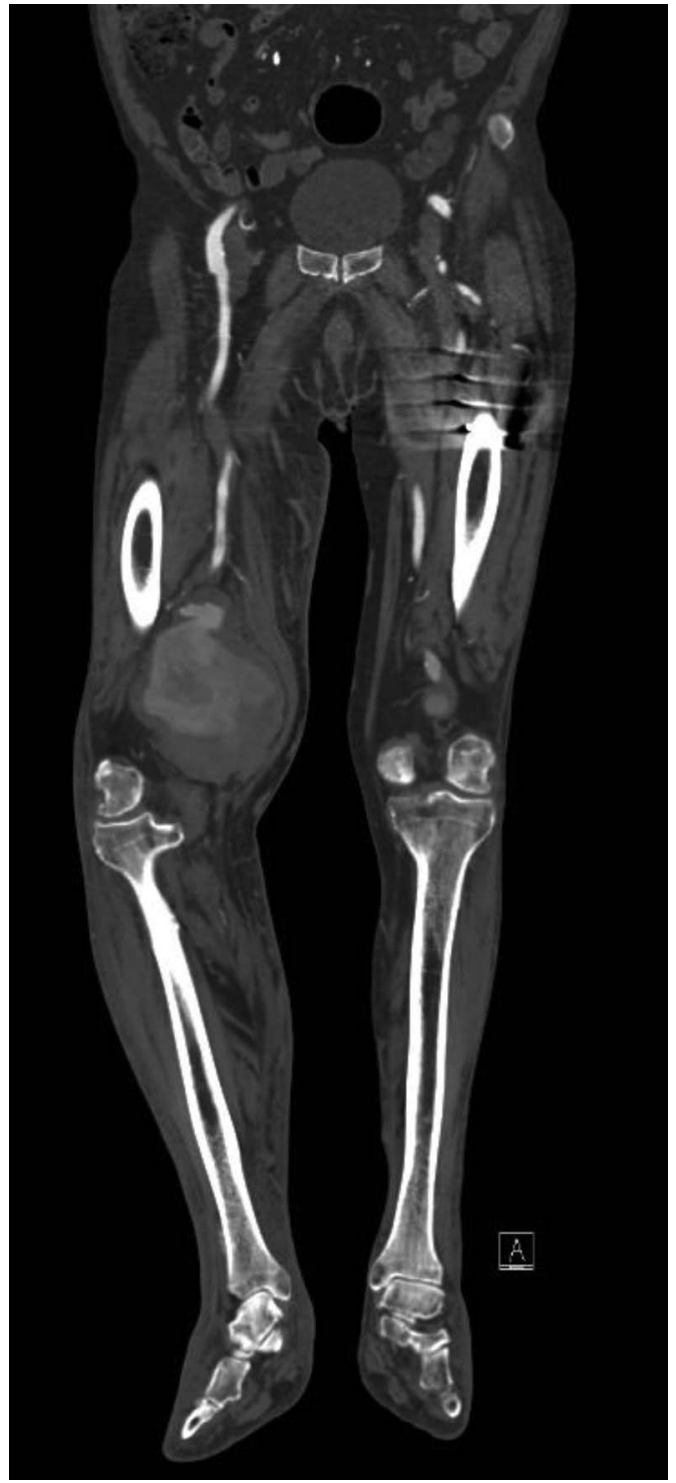

Figure $2 \mathrm{CT}$ angiogram of both legs. There is a right ruptured popliteal aneurysm with surrounding haematoma.

cause of leg swelling where there are few case reports documenting popliteal aneurysms of this size and it is even less common to present as a life threatening, ruptured popliteal artery aneurysm. ${ }^{3}$ 


\section{Learning points}

- When confronted with suspected deep vein thrombosis, always examine all relevant peripheral pulses.

- Always aim to identify the cause for a swollen right leg and to consider both surgical and medical causes, rather than only to exclude deep vein thrombosis.

- Overlying haematoma of the popliteal artery aneurysm may have prevented the clinician from being able to palpate the aneurysm and may have subsequently been missed on ultrasound if the request did not include suspicion for an aneurysm. Therefore, further imaging is recommended if the cause for a patient's presentation has not been identified.

\section{Patient consent Obtained.}

Provenance and peer review Not commissioned; externally peer reviewed.

\section{REFERENCES}

1 Ely JW, Osheroff JA, Chamberliss L, et al. Approach to leg edema of unclear etiology. J Am Board Fam Med 2006;19:148-60.

2 Galland RB. Popliteal aneurysms: from John Hunter to the 21st century. Ann R Coll Surg Eng/ C;89:466-71.

3 Goncu T, Tiryakioglu O, Sezen M, et al. Giant popliteal aneurysm with deep vein thrombosis, foot drop and arteriomegali. BMJ Case Rep 2009;2009:bcr11.2008.1248.

Contributors WL, wrote the majority of this report with support from KS.

Competing interests None.

Copyright 2014 BMJ Publishing Group. All rights reserved. For permission to reuse any of this content visit

http://group.bmj.com/group/rights-licensing/permissions.

BMJ Case Report Fellows may re-use this article for personal use and teaching without any further permission.

Become a Fellow of BMJ Case Reports today and you can:

- Submit as many cases as you like

- Enjoy fast sympathetic peer review and rapid publication of accepted articles

- Access all the published articles

- Re-use any of the published material for personal use and teaching without further permission

For information on Institutional Fellowships contact consortiasales@bmjgroup.com

Visit casereports.bmj.com for more articles like this and to become a Fellow 